\title{
SERUM LEAD, COPPER AND ZINC IN CHILDREN WITH BRONCHIAL ASTHMA
}

\author{
Wagdy A. Elsayed, Shahenaz H. Alkalyouby and Eman Essa \\ Department of Pediatric and Clinical Pathology, Benha teaching hospital
}

Corresponding

Author:

Wagdy A. Elsayed

Email:

wagdyattia@yahoo.com
ABSTRACT

Background: Bronchial asthma is chronic inflammatory of the lung airways resulting in episodic airflow obstruction. Lead exposure results in alteration of immune system function resulting in asthma. Zinc, copper are component of antioxidant system and alteration of their level affect increase risk of asthma.

Objective:. Determine the serum level of lead, zinc, copper in children with bronchial asthma and study their relation to development of asthma

Patients and methods: The patient group included 38 full-term newborn infants diagnosed as having bronchial asthma who were selected from pediatric department Benha Teaching Hospital. The control group included 17 healthy child age and sex matched C-reactive protein (CRP) were measured by the ELISA technique (highly sensitive CRP). ESR was performed by the Wintrobe method, Serum lead was determined by atomic absorption method. Serum copper and zinc were determined by calorimetric method.

Results: Serum copper and zinc were elevated in asthmatic children compared to controls with no relation to clinical manifestations or laboratory parameters .Serum lead showed no difference among patients and controls however it increased in severe cases compared moderate and mild cases and correlated positively with duration of admission.

Conclusion:. : We determined serum copper, zinc and lead in children with bronchial asthma. We found elevated serum copper and zinc in asthmatic children compared to controls with no relation to clinical manifestations or laboratory parameters .Serum lead showed no difference among patients and controls, however it increased in severe cases compared moderate and mild cases and correlated positively with duration of admission. These results indicate importance of environmental exposure as a risk factor of asthma in children

Keywords: Bronchial asthma ,Children, Copper Zinc ,Lead

\section{INTRODUCTION \& OBJECTIVE}

A sthma is a chronic inflammatory condition airflow obstruction. Different etiological factors including genetic, environmental are involved in development of asthma (1)Epidemiological study of asthma revealed that asthma still common among lower socioeconomic classes including African Americans and Hispanics two to four times relative to Caucasians. Among possible environmental factors of asthma lead and cupper exposure. (2)

The epidemiology of pediatric asthma and that of lead poisoning are similar. Both are prevalent among minority of children, and some elements in the physical environment increase risk of disease (3).Low socioeconomic stander and residing in an urban setting are associated with increased risk for both conditions (4).

Published an analyses suggest that lead exposure may result in alterations to immune system components known to be associated with asthma (5).Lead has been associated with the increased production of total immunoglobulin E (IgE), which is also observed in atopic and non-atopic individuals with asthma (6) In experimental animals lead exposure resulted in asthma like disease (7) .

Children are at risk of chronic lead exposure because of their proximity of ground and soil and putting objects in mouth .Other possible sources, dust, and contaminated diet, breast milk of mother, contaminated drinking water, improper manufactured Chocolate, and candy (8)

There is increasing evidence that reactive oxygen species can be of particular importance in the pathophysiology of several lung diseases. Reactive oxygen species can even induce an autonomic imbalance between muscarinic receptor-mediated contraction and the beta-adrenergic-mediated relaxation of the pulmonary smooth muscles (9). Increased tissue 
vulnerability to oxidant stress is likely to increase the risk of development of asthma (10).

Copper, zinc are important component of anti-oxidant system , super oxide dismutase (11) and Changes in their level decrease the efficiency of this antioxidant systems and this leads to hyper-reactivity and inflammation in the respiratory tract(12)

Copper was supposed to have antioxidant(13) and anti-inflammatory(14) function related and protects against chronic obstructive airway disease in animal models (15). While some reports described its higher level may be associated with development of asthma and infant wheezes possible due to environmental exposure (16\&17\&18), other reported low level (19)

Zinc is an essential trace element acquired by dietary means. It plays a central role in modulating the immune system and is essential for cellular function in the immune response as well as acting as an antioxidant [20]. While some reports described zinc deficiency in children with asthma (18), others described high (19) and normal level (21)

For the possible role of these elements in pathogenesis in bronchial asthma in children, which may be reflected on management, we determined serum lead, copper, and zinc in children with bronchial asthma.

\section{SUBJECTS\&METHODS}

Patients group: Thirty eight children diagnosed as bronchial asthma with age ranged from 24 - 101 months was ${ }^{\mathrm{i}}$ chosen from pediatric department in Banha Teaching Hospital. Detailed history, physical examination was done for all cases .Complete nutritional history was done at infant ,toddler ,preschool ,school ages. Socio-demographic data was obtained including: localities, housing, parent occupation, educational level, smoking. These patients were compared with 17 healthy controls.

Diagnosis of asthma based on history of recurrent acute attack of cough ,dyspnea and wheezes in child more than 2 years in response to provocation which is associated with impaired lung function " in 6ys or older " and improved with bronchodilator $\beta$ agonist in addition to family history and eosinophilia. Respiratory function (FEV) was assessed in children older than 6 years in absence of other causes of wheezing (16)

Exclusion criteria cases with possible causes of wheezes other than asthma as congenital lung lesion ,reflex disease, cardiac , chest diseases other than asthma,.Also cases with severe other systemic illness, protein energy malnutrition were excluded .

Severity of acute attack of asthma was classified as:1-mild : presented with mild distress only with excretion, end expiratory wheeze ,pulse 100/minute , $\mathrm{O}_{2}$ saturation $>95 \%$. .2-moderate: presented with distress on rest with difficult feeding, loud whole expiratory wheezes pulse rate 100-120/minute , $\mathrm{O}_{2}$ sat 90-95 3-severe: distress on rest stop feeding ,loud wheezes expiratory ,inspiratory , pulse $>120$ /minute, $\mathrm{O}_{2}$ saturation $<90 \%$ (1)

The control group: were selected from 1ry health care center coming for routine care as immunization, complains not related to infection, infestation, allergy or chest diseases. Those with history suggest respiratory illness in last one month or any history suggest asthma or recurrent cough were excluded. In addition, those with family history suggest asthma or atopic diseases were excluded.

\section{Laboratory and radiological investigations:}

Laboratory investigations including CBC with peripheral smear was done, CRP was determined by ELIZA "high sensitive CRP". ESR done by Win Trobe method.

Blood sampling: Three mls of blood were taken at 24 hours of age from both cases and controls and left for 20 minutes at $37{ }^{\circ} \mathrm{C}$. Serum was separated after centrifugation and kept at $20{ }^{\circ} \mathrm{C}$ until analysis.

Radiological investigations : chest $\mathrm{x}$ ray was done routinely for all cases included in the study. C. T. scan was done for cases suspected to have another cause of wheezing other than asthma . 
Determination of serum lead: Serum lead was determined by atomic absorption spectroscopy.

Principle of test: atomic absorption depends on that elements in ground "atomic" state absorb light at specific wavelengths. Metal ions in a solution are converted to atomic state by means of a flame. Light of the appropriate wavelength is supplied and the amount of light absorbed can be measured against a standard curve. The technique of flame atomic absorption spectroscopy (FAAS) requires a liquid sample to be aspirated, aerosolized, and mixed with combustible gases

Steps of measurement of lead ::a-open power and gas pressure regulator of the device b-set item to surrounding lamb, adjust wave length of element c-introduce sample for measurement dthe computer assigns element concentration in the sample .

Determination of serum Copper: Serum copper was measured by calorimetric method by kit provided Centronic GmbH (Germany).

Principle of test: Copper forms with(3,2Dibromo-2-pyridyiazo) Methyl-N-sulfapropyl-aniline a chelate complex. The increase of absorbance of the complex can be measured and is proportional to the total copper in the sample.

Determination of serum zinc: was measured by a colorimetric method by a kit from Centronic GmbH (Germany).

Principle of test:

Zinc forms a red chelate complex with 2- (5Brom -2- pyridyazo) -5-(-V-Propyl-N-Sulfoprpylamino)-pbeal The increase of absorbance of the complex can be measured and is proportional to the total zinc in the sample.

Legal, ethical aspect: Written consents have been taken from the parents of all the children included in this study. The study also was approved from the Research Ethics Committee in General Organization for Teaching Hospital and Institutes in Cairo

Statistical Analysis: Data were analyzed using SPSS 20 computer program (IBM, Endicott, Broome County, New York, United States). Data were expressed as mean \pm SD for parametric data .When data are non-parametric data expressed as median, range . Tests of significance "Chi-square and T tests" and correlation "Pearson's" study were done for parametric data where appropriate $\mathrm{P}<0.05$ was statistically significant. Non-parametric tests "Man-Whitney for significance, Spearman's correlation " were used when data are nonparametric

\section{RESULTS}

The study included 55 children 38 cases diagnosed as bronchial asthma, 17 healthy children taken as controls. No significant statistical differences was found between cases and controls regarding age, sex and weight $(\mathrm{P}$ was $0.801,0.949$ and 0.195 respectively) "Table 1"

\section{Clinical characteristics of patients group: "Table 2"}

Ten $(26.32 \%)$ cases had nasopharyngitis with low-grade fever, 6 cases had naso-pharyngitis without fever. (15.79 \%) None of cases or controls showed evident clinical manifestation of anemia.. Nine (23.68 $\%)$ asthmatic cases presented in mild attack, 19 $(50 \%)$ cases presented in moderate attack and $10(26.32 \%)$ cases presented in severe attack.

Laboratory parameters of the patient and controls: "Table 3"

Asthmatic children showed lower $\mathrm{Hb}$ ,Hct , RBC, (P was 0.001,0.008, 0.004, respectively)

Asthmatic children showed higher ESR compared to controls ( $\mathrm{P}$ was 0.000) .No significant differences between cases and controls regarding $\mathrm{WBCs}$ and platelets ( $\mathrm{P}$ was $0.069,0.829$ respectively).

Also Asthmatic children showed higher level of serum Zinc and copper compared to controls.( $\mathrm{P}$ was $0.00 \& 0.00$ respectively). While no difference in serum lead was found, ( $\mathrm{P}$ was 0.457). Serum lead it was detectable in 26 of 38 cases $(68.4 \%)$ compared to 11 of 17 controls $(64.7 \%)$ " P was 0.786 ".

Clinical data relation to Zinc, Copper and Lead: "Table 4"

Asthmatic cases who had fever did not show significant differences with those without 
fever regarding serum Zinc, Copper and Lead ( $\mathrm{P}$ was $0.232,0.882$ and 0.105 respectively). Cases with naso-pharyngitis showed no significant difference with those without naso pharyngitis regarding these parameters $(\mathrm{P}$ was 0 $.0 .79,0.782$ and 0.311 , respectively.)

Mild, Moderate and severe cases of asthma showed no differences regarding serum zinc, copper using one-way ANOVA ( $\mathrm{P}$ was $0.153,0.491$ respectively).

Serum lead was significantly different among mild, moderate and severe cases of asthma using non-parametric Kruskal-Wallis test ( $\mathrm{P}$ was 0.002). Subgroup analysis using Mann-Whitney test revealed no significant difference between mild and moderate cases ( $\mathrm{P}$ 0.3318 ) while severe cases showed higher lead values compared to mild and moderate cases using the same test ( $\mathrm{P} 0.0019$ was 0.0061 respectively) "data not shown"

Zinc, Copper and Lead correlation with Age, Weight, Duration of Admission and Hematological Parameters ."Table 5"

Serum zinc, copper, and lead had no significant correlation with age, weight, RBCs, $\mathrm{Hb}$ and $\mathrm{WBCs}$

Serum zinc showed significant positive correlation with platelets ( $\mathrm{P}$ was 0.015$)$ while copper and lead had no significant correlation.

Serum lead has significant positive correlation with duration of admission ( $\mathrm{P}$ was 0.002 ), while zinc and copper has no significant correlation.

Table (1): Clinical Parameters in Patients, Controls

\begin{tabular}{|c|c|c|c|c|}
\hline & & Cases n=38 & Controls $n=17$ & $\mathrm{P}$ \\
\hline \multirow{2}{*}{ Age (months) } & $\ddot{\mathrm{X}} \pm \mathrm{SD}$ & $39.68 \pm 17.55$ & $38.35 \pm 19.16$ & \multirow{2}{*}{$0.801 \mathrm{NS}$} \\
\hline & Range & $24-101$ & $24-99$ & \\
\hline \multirow{2}{*}{ Sex } & Females & $16-42.1 \%$ & $7-41.2 \%$ & \multirow{2}{*}{$0.949 \mathrm{NS}$} \\
\hline & Males & $22-57.9 \%$ & $10-58.8 \%$ & \\
\hline \multirow{2}{*}{ Weight (kg) } & $\ddot{\mathrm{X}} \pm \mathrm{SD}$ & $14.64 \pm 3.48$ & $16 \pm 3.71$ & \multirow{2}{*}{$0.195 \mathrm{NS}$} \\
\hline & Range & $10-27$ & $12-29$ & \\
\hline
\end{tabular}

Table (2): Clinical data of the patients group

\begin{tabular}{cccc}
\hline \multirow{2}{*}{ C inical data } & & Number & Frequencies \\
\hline \multirow{3}{*}{ Naso pharyngitis } & +ve with Fever & 10 & $26.31 \%$ \\
\cline { 2 - 4 } & +ve no fever & 6 & $15.79 \%$ \\
\cline { 2 - 4 } & No Nasopharyngitis & 22 & 57.9 \\
\cline { 2 - 4 } Fever & +ve & 12 & $31.5 \%$ \\
& -ve & 26 & $68.5 \%$ \\
\hline \multirow{2}{*}{ Severity of attack } & Mild & 9 & $23.68 \%$ \\
& moderate & 19 & $50 \%$ \\
\cline { 2 - 3 } & Severe & 10 & $26.32 \%$ \\
\hline
\end{tabular}


Table (3): Cases versus controls regarding the laboratory data

\begin{tabular}{|c|c|c|c|c|}
\hline \multicolumn{2}{|c|}{ Laboratory data } & \multirow{2}{*}{$\begin{array}{c}\text { Cases }=38 \\
10.72 \pm 1.49\end{array}$} & \multirow{2}{*}{$\begin{array}{c}\text { Controls }=17 \\
12.16 \pm 1.11\end{array}$} & \multirow{3}{*}{$\begin{array}{c}\mathbf{P} \\
0.001\end{array}$} \\
\hline \multirow{2}{*}{$\mathrm{Hb}(\mathrm{gm} / \mathrm{dl})$} & $\ddot{\mathrm{X}} \pm \mathrm{SD}$ & & & \\
\hline & Range & 8-14 & $10-14$ & \\
\hline \multirow{2}{*}{ Hct $(\%)$} & $\ddot{\mathrm{X}} \pm \mathrm{SD}$ & $33.329 \pm 6.02$ & $37.76 \pm 3.58$ & \multirow{2}{*}{0.008} \\
\hline & Range & $22-47$ & $33-49$ & \\
\hline \multirow{2}{*}{$\operatorname{RBCs}\left(\times 10^{6}\right)$} & $\ddot{\mathrm{X}} \pm \mathrm{SD}$ & $3.9 \pm 0.86$ & $4.43 \pm 0.41$ & \multirow{2}{*}{0.004} \\
\hline & Range & $2.7-6.22$ & $3.8-5.1$ & \\
\hline \multirow{2}{*}{ WBCs $\left(\times 10^{3}\right)$} & $\ddot{\mathrm{X}} \pm \mathrm{SD}$ & $9.01 \pm 2.95$ & $11.92 \pm 16.27$ & \multirow{2}{*}{0.069} \\
\hline & Range & $4-15$ & $5-11$ & \\
\hline \multirow{2}{*}{ Platelets $\left(\times 10^{3}\right)$} & $\ddot{\mathrm{X}} \pm \mathrm{SD}$ & $361.26 \pm 139.36$ & $352.94 \pm 111.9$ & \multirow{2}{*}{0.829} \\
\hline & Range & $110-625$ & $150-560$ & \\
\hline $\mathrm{CRP}(\mathrm{mg} / \mathrm{dl})$ & & $00-00$ & $00-00$ & \\
\hline \multirow{2}{*}{ ESR } & $\ddot{\mathrm{X}} \pm \mathrm{SD}$ & $20.26 \pm 6.77$ & $9.71 \pm 2.37$ & \multirow{2}{*}{0.00} \\
\hline & Range & $10-40$ & $5-15$ & \\
\hline \multirow{2}{*}{ Serum Zinc } & $\ddot{\mathrm{X}} \pm \mathrm{SD}$ & $249.63 \pm 93.97$ & $148.47 \pm 60.924$ & \multirow{2}{*}{0.00} \\
\hline & Range & $115-556$ & 104-170 & \\
\hline \multirow{2}{*}{ Serum Copper } & $\ddot{\mathrm{X}} \pm \mathrm{SD}$ & $183.18 \pm 44.228$ & $126.06 \pm 15.986$ & \multirow{2}{*}{0.00} \\
\hline & Range & $90-277$ & $108-170$ & \\
\hline \multirow{3}{*}{$\begin{array}{c}\text { Serum Lead } \\
\text { "Man whitny U test" } \\
\text { Non-parametric }\end{array}$} & Median & 1.215 & 1.1 & \multirow[b]{3}{*}{0.457} \\
\hline & Range & $00-8.21$ & $00-3.1$ & \\
\hline & Mean rank & 29.05 & 25.65 & \\
\hline
\end{tabular}

Table (4) Clinical data relation to with Zinc, copper and lead

\begin{tabular}{|c|c|c|c|c|}
\hline \multirow{4}{*}{ Fever } & & Zinc & Copper & Lead \\
\hline & +ve 12 & $222.5 \pm 69.95$ & $181.58 \pm 34.27$ & Median1.095(0-4) \\
\hline & -ve 26 & $262.15 \pm 101.976$ & $183.92 \pm 48.75$ & Median1.56(0-9) \\
\hline & $\mathrm{P}$ & $0.232 \mathrm{NS}$ & 0.882 & $0.105 \mathrm{NS}$ \\
\hline \multirow{3}{*}{$\begin{array}{c}\text { Acute } \\
\text { naspharyngitis }\end{array}$} & +ve 16 & $254.5 \pm 112.46$ & $185.56 \pm 44.118$ & Median 0.95(0-4) \\
\hline & -ve 22 & $248.09 \pm 80.75$ & $181.54 \pm 45.264$ & $1.005(0-9)$ \\
\hline & $\mathrm{P}$ & $0.79 \mathrm{NS}$ & $0.782 \mathrm{NS}$ & $0.3117 \mathrm{NS}$ \\
\hline \multirow{5}{*}{ Asthma severity } & Mild & $210.56 \pm 49.518$ & $188.44 \pm 37.74$ & Median 0(0-2.38) \\
\hline & Moderate & $245.16 \pm 87.504$ & $174.74 \pm 43.292$ & Median 0.73(0-8.21) \\
\hline & Severe & $293.3 \pm 122.96$ & $183.18 \pm 44.228$ & Median 3.88(0-9) \\
\hline & F"ANOVA" & 1.979 & 0.727 & Kruskal-Wallis test \\
\hline & $\mathrm{P}$ & 0.153 & 0.491 & 0.002 \\
\hline
\end{tabular}


Table (5) Zinc, Copper, and Lead correlation with Age, Weight, Duration of Admission, and Hematological Parameters

\begin{tabular}{ccccccccc}
\hline & & Age & Weight & $\begin{array}{c}\text { Duration of } \\
\text { admission }\end{array}$ & RBCs & Hb (gm/dl) & WBCs & Platelet \\
\hline Zinc & $\mathrm{R}$ & 0.044 & 0.061 & 0.048 & 0.004 & 0.037 & 0.042 & $0.392^{*}$ \\
"Persons" & $\mathrm{P}$ & 0.792 & 0.715 & 0.776 & 0.98 & 0.827 & 0.802 & 0.015 \\
\hline Copper & $\mathrm{R}$ & 0.027 & 0.066 & -0.136 & -0.134 & -0.066 & -0.271 & 0.100 \\
"Persons" & $\mathrm{P}$ & 0.872 & 0.694 & 0.334 & 0.424 & 0.694 & 0.10 & 0.552 \\
\hline Lead & $\mathrm{R}$ & 0.222 & 0.084 & $0.485^{* *}$ & -0.194 & -0.213 & 0.037 & 0.262 \\
"Spearman,s" & $\mathrm{P}$ & 0.181 & 0.617 & $0.002 \mathrm{HS}$ & 0.244 & 0.198 & 0.827 & 0.112 \\
\hline
\end{tabular}

\section{DISCUSSION}

In this study, we investigated 38 children diagnosed as asthma for serum lead, copper and zinc compared to 17 age, sex and weight matched control. Zinc and copper are considered trace elements and are important component of antioxidant enzymes (22), they are also heavy metals and are possible source of environmental pollutants and toxicity (23).

Asthmatic children showed lower $\mathrm{Hb}$, Htc ,RBCs and ESR compared to controls .No difference was observed regarding WBCs and platelets between both groups. Our previous reports of revealed similar results in asthmatic children. $(24,25)$ Association of anemia with asthmatic children can be explained on basis that asthma is associated with acute or chronic inflammation which causes anemia ( 26 ), also anemia may be a possible risk factor of asthma in many reports $(25,27,28)$. ESR is expected to be elevated in asthma because of associated acute and chronic inflammatory reaction (1)

Asthmatic children showed higher serum copper compared to controls.Also it showed no differences or correlations in relation to clinical or laboratory parameters among asthmatic children .While some studies in agreement with our results $(18,29,30)$, other studies showed low level of copper in asthmatics $(19,31)$ .However these last two studies done in adult asthmatics . Copper contaminant now is public health problem. Children are more risky than adults for copper exposure .Beside common environmental exposure risks of children as small body size, hand mouth behavior, drinking excess water (32)., infants and children up to 10 years of age have increased susceptibility to copper toxicity because of a normally high concentration of copper in the liver during early life and the lack of a fully developed homeostatic mechanism of copper contaminant in children under 10 years of age. (33). Water and food are the main sources for copper exposure beside air and soil (34).

May studies proposed that reactive $\mathrm{O}_{2}$ species (ROS), oxidative stresses play important role in pathogenesis of asthma and allergic diseases $(35,36$, and 37). Copper oxide nanoparticles in ambient air were found to cause increased oxidative stresses in human respiratory epithelial cells (HRECs) compared to iron and silicon (38). Copper ion in ambient air induced increased ROS and pro inflammatory cytokine release (IL-6 and IL-8) in HRECs (39)

Asthmatic children showed higher serum zinc in relation to controls . Among asthmatic children serum zinc did not show any relation to clinical manifestations however serum zinc showed positive correlation with platelets with no relation to other laboratory parameters. No available explanation for positive correlation of zinc with platelets. Further studies is required to explain this correlation.

Elevated serum zinc in asthmatic children is unexpected. However, some reports support this finding. Hussein et al 2008(19) found elevated serum zinc in adult asthmatics. They attributed their finding to low serum copper . Another study in elderly asthmatics has the 
same finding (40).One Japanese study found that asthmatic adult female has higher zinc level similar controls (41). No available study has similar finding in children., however some reports support our finding. Ambient metals exposure , fine particle "PM 2.5" was associated with increased risk of development of asthma in children (42). Increased Ambient air zinc concentration was associated with increased asthma morbidity including emergency department "ED" visits, ,hospital admissions (42). Intra-tracheal exposure to metals particulate matter filter extracts "including zinc" was associated with acute pulmonary toxicity including asthma like pathology (44). Zinc oxide nanoparticles induced pathological changes occurs in asthma as pulmonary eosinophilia, release of IL-13, IL1 $\beta$ and goblet cell hyperplasia, increased serum IgE in rat model (45).

Increased zinc level in children is not surprising. Zinc is not only trace element but also considered as heavy metal and is a source of environmental pollutant as mentioned before (23). Certain populations receive greater-thanaverage exposures to zinc from environmental sources. For example, higher levels of zinc have been reported in soil and water near waste sites, metal smelters, and areas exposed to untreated waste water, those who have galvanized plumbing in their residences are at risk of zinc contamination Children are at more prone to risk of exposure and contamination than adult. Children drink more water breath more air (46) Child behavior as playing in ground, soil putting hand in mouth, more proximal to ground.(32). Our previous study in wheezy infant revealed no difference in zinc level between wheezy infant and healthy controls . The difference in result from current study is expected.Wheezy infants have lower age range (0-24 mo.) and possible different etiology, pathogenesis and outcome from asthmatic children (47). Older children in current study with age range 24-101 mo) are at more risk of environmental contaminants. Young infant are easily controlled in feeding and in keeping away from soil, dust exposure.
Contrarily to our results low level of zinc were found in asthmatic children $(48,49)$ and adults (22). Also zinc supplementation reduced airway inflammations and hyperresponsiveness to common allergen in mouse (50) and reduced asthma severity in asthmatic children (51). Normal level of zinc was found in asthmatic children by Ghaffari et al (52).

The explanation of contradiction in the literature about zinc level in asthmatic children has different possibilities including methods of determination, different socioeconomic classes, and environmental conditions, and effect of treatment (19). Low serum zinc levels was found in corticosteroid-treated asthmatic patients (children and adults)compared to nontreated asthmatics(53).Another possibility that zinc deficiency as well zinc excess may be a risk factor of asthma in children . As mentioned before, ROS, oxidative stresses play important role in pathogenesis of asthma and allergic diseases $(35,36$, and 37). Superoxide dismutase is antioxidant enzyme contain zinc and copper in their structure. It possible that any disturbance in zinc and copper level will affect activity and function of the enzyme (18) Increased zinc level or its derivative is hazardous and toxic to lung $(54,55$, and 56) and generates oxidative stresses and pulmonary eosinophilia (44).

Asthmatic children showed no differences regarding serum lead with controls. Severe, moderate and mild asthmatics showed differences in their serum level. In agreement with these finding Mohammed et al 2015 found no difference between asthmatic patients and healthy controls in serum lead while serum lead > $10 \mathrm{mg} / \mathrm{dl}$ associated with increased severity of asthma and development of eosinophilia and elevated $\operatorname{IgE}$ (57), however they found higher mean values $(13.3,11.4$ $\mu \mathrm{gm} / \mathrm{dl}$ ) of lead among patients and controls compared with our study . Previous studies showed that higher blood lead has no relation with development of asthma $(57,58)$.while other studies $(29,51)$ showed that higher lead were found in asthmatic patients compared to controls. These last 2 studies despite apparent 
similar finding demonstrated variation in serum lead in both patients and controls (8.2 \pm 3.1 , $5.7 \pm 2.3 \mu \mathrm{g} / \mathrm{dl}$." Egyptian study " vs $5 \pm 2.46$, $3.68 \pm 1.83 \mu \mathrm{g} / \mathrm{d}$ "Iranian study" ) but still has higher values of than our study. In Argentina serum blood level of lead in children was found in range 1.1-3.6 $\mu \mathrm{g} / \mathrm{dL}$ with median value 2.2 $\mu \mathrm{g} / \mathrm{dL}(60)$ These data showed the distribution and median value near our value. It is expected to find different values of serum lead among different studies in different populations with different risk factors of exposures and local governmental precautions against exposure.

In our study no correlation between serum lead and hematological or other laboratory parameters as shown in other studies $(57,29)$. This can be explained because of lower values of lead in our patients compared with previous studies. Our values still considered lowest values among Egyptian studies. No apparent explanation for this difference apart from this study is not epidemiological study with small number of patients with no available study in same localities for comparison. Joseph et al 2005 (61) found that the threshold of blood lead as a risk of asthma development varies among African Americans and Caucasians. They suggested different factors including asthma phenotype, race, and genetic susceptibility interact with lead exposure for development of asthma. This can explain contradiction in previous studies in different localities and different population in this issue.

Despite our lower values of serum lead, severe asthmatic cases showed higher serum lead compared to mild and moderate cases, also serum lead correlated with admission days. Lead is not natural element in human body. So it is supposed that no threshold below which no adverse effect are observed $(62,63)$. It is possible that lead at certain level is not a risk factor for asthma but can increase it severity. This require further investigation with larger population study. Admission days is expected to correlate with asthma severity for longer time of management, this can explain its correlation with serum lead in asthmatic children
Some limitation in our study that we studied 3 elements in one study. At the study plan, we did not expect environmental contaminant as determinant of our results. Environmental determinants needs larger epidemiological studies including bigger sample size for each element alone with comprehensive investigation of environmental exposure. Also we included younger pediatric age randomly which is more risky for environmental exposure than older age. Larger epidemiological studies including all pediatric age with detailed social, nutritional history about environmental exposure and possible contamination is required .

Conclusion: We determined serum copper, zinc and lead in children with bronchial asthma. We found elevated serum copper and zinc in asthmatic children compared to controls with no relation to clinical manifestations or laboratory parameters .Serum lead showed no difference among patients and controls, however it increased in severe cases compared moderate and mild cases and correlated with duration of admission. These results indicate importance of environmental contaminants in development of asthma in children.

\section{ACKNOWLEDGEMENTS}

We thank all staffs in NICU Benha Teaching Hospital for their cooperation in completing this work.

\section{CONFLICTS OF INTEREST}

None of the authors has any conflicts of interest to declare

\section{REFERENCES}

1- Liu A H ,Spahn J D and Leung D Y. M:Childhood Asthma, In Nelson Textbook of Pediatrics, $18^{\text {th }}$ ed. Copyright (C) 2007 Chapter 138: 780-800,eds.. Kliegman R. M,. Behrman R. E, Jenson H. B., Stanton B. F., Saunders, An Imprint of Elsevier

2-CDC (Centers for Disease Control and Prevention). 2002. Surveillance for asthmaUnited States, 1980-1999.MMWR Surveil Summ 51(SS01):1-13.

3- Hartert TV, Peebles RS Jr. Epidemiology of asthma: the year in review. Curr Opin Pulm Med 2000, 6:4-9. 
4-Bernard SM, McGeehin MA.Prevalence of blood lead levels $>$ or $=5$ micro g/dL among U.S. children 1 to 5 years of age and socioeconomic and demographic factors associated with blood of lead levels 5 to 10 micro g/dL, Third National Health and Nutrition Examination Survey, 1988-1994. Pediatrics 2003, 112(6 pt 1):1308-1313.

5. Sun Li, Hu J, Zhao Z, Lon L, Cheng $H$. Influence of exposure to environmental lead on serum immunoglobulin in preschool children. Environ Res 2003, 92:124-128.

6.Romanet-Manent S, Charpin D, Magnan A, Lanteaume A, Vervloet D. Allergic vs. non allergic asthma: what makes the difference? Allergy 2002;57(7):607-613

7. Farkhondeh T, Boskabady MH Mohammd Kazem Koohi MK, Sadeghi-Hashjin G and Moin M The Effect of Lead Exposure on Selected Blood Inflammatory Biomarkers in Guinea pigs Cardiovascular \& Hematological Disorders-Drug Targets, 2013, 13, 45-49

8. Levin R, Brown MJ, Kashtock ME, Jacobs DE , Whelan EA and Rodman J,et al, Lead Exposures in U.S. Children, 2008: Implications for Prevention Environ Health Perspect,2008, 116:1285-1293.

9. DOELMAN, C.J., BAST, A. Oxygen radicals it1 lung pathology. Free Radic. Biol. Med. 1990; 9; 5:381-400

10. GREENE, L.S. Asthma and oxidant stress; nutritional, environmental and genetic risk factors. J. Am. Coll. Nutr. 1995; 14; 4:317-324

11. Kinnula VL, Crapo JD. Superoxide dismutases in the lung and human lung diseases. Am J Respir Crit Care Med. 2003 Jun 15;167(12):1600-19.

12. cheu S, Coudray C, Tresallet N, Favier A, de Leiris J..Effect of dietary antioxidants trace elements supply on cardiac tolerance to ischemia reperfusion in rat. J Mol Cell Cardiol 1995; 27:2303-14.

13-Denko C: Protective role of ceruloplasmin in inflammation. Agents Actions 1979:9, 333-334.

14-O'Dell B, Kilburn K, McKensie W \& Thurston R: The lung of the copper-deficient rat. Am. J. Pathol. 1978:91, 413-432.

15-Maritz G \& Windvogel S: Is maternal copper supplementation during alveolarisation protecting the developing rat lung against the adverse effects of maternal nicotine exposure? A morphometric study. Exp. Lung Res 2003: 29, 243-260.
16- GINA. Global Initiative for Asthma. Pocket guide for management and prevention of asthma. 2010; 6-7. Available from: http://www ginasthma.org. Accessed December 5, 2014.

17-Kennedy, T., A. J. Ghio, W. Reed, J. Samet, J. Zagorski, J. Quay, J. Carter, L. Dailey, J. R. Hoidal, and R. B. Devlin.. Copper-dependent inflammation and nuclear factor- $\square \mathrm{B}$ activation by particulate air pollution. Am.J. Respir. Cell Mol. Biol. 1998, 19:366-378.

18- Vural h., Uzun K., Uz E., A. Kowigit, A. igli and Akyol O.,1. Concentrations of copper, zinc and various elements in serum of patients with bronchial asthma J. Trace Elements Med. Biol. June 2000, 14, 88 - 91

19- Hussein MH, Yousif AA,and Saeed AM Serum Levels of Selenium, Zinc, Copper and Magnesium in Asthmatic Patientsa Case Control Study.. Sudan JMS 2008,3, 1:45-49

20- Shankar AH, Prasad AS 1998: Zinc and immune function: the biological basis of altered resistance to infection. Am J Clin Nutr, 68:447463.

21- Kocyigit A ${ }^{\square}$,Armutcu F Gurel A and Ermis B Alterations in plasma essential trace elements selenium, manganese, zinc, copper, and iron concentrations and the possible role of these elements on oxidative status in patients with childhood asthma 2004, 97, $1: 31-41$

22-Vural H1, Uzun K, Uz E, Koçyigit A, Cigli A, Akyol O. Concentrations of copper, zinc and various elements in serum of patients with bronchial asthma. J Trace Elem Med Biol 2000; 14(2): 88-91.

23-Zamani A A , Yaftian M R and Zamani A P et al Multivariate statistical assessment of heavy metal pollution sources of groundwater around a lead and zinc plant. Iranian Journal of Environmental Health Sciences \& Engineering 2012, 9, 29:1-10

24-Elsayed WA, and Amer ER ,Serum 25-OH vitamin D In Children With Bronchial Asthma, Z.U.M.J.2014,20: (1) ,119-126

25- El-Sayed WA, and Amer ER Iron deficiency anemia in children with bronchial asthma Z.U.M.J (in press)

26-Lanzkowsky P. Classification and Diagnosis of Anemia in Children, In Manual of Pediatric Hematology and Oncology $5^{\text {th }}$ ed. Copyright (C) 2011 chapter 1:1-12 ed Lanzkowsky P ,Academic Press is an imprint of Elsevier 32 Jamestown Road, London NW1 7BY, UK 
27- Ramakrishnan K and Harish PS. Hemoglobin level as a risk factor for lower respiratory tract infections. Indian J Pediatr. 2006;73:881-3

28-- Eissa SF, Mohammad AA , Ibrahim SA, Abd-Elgwad ER, Soliman NSA Iron deficiency anemia as a risk factor in childhood asthma Egyptian Journal of Chest Diseases and Tuberculosis 2016, 65: 733-737

29- El Sherbeny MM , Ola G. Behairy OG, Mohammad OI, Elsayed AM: Serum levels of lead and copper in a group of Egyptian children with bronchial asthma Egypt J Pediatr Allergy Immunol 2016;14(2):47-52.

30- El-Kholy MS, Gas Allah MA, el-Shimi S, elBaz F, el-Tayeb H, Abdel-Hamid MS. Zinc and copper status in children with bronchial asthma and atopic dermatitis J Egypt Public Health Assoc 1990;65(5-6):657-68.

31- Role of serum trace elements magnesium, copper and zinc, level in Libyan patients with bronchial asthma $\mathrm{Al}$-salhen $\mathrm{KS}$, Mahmoud SAM , Omran SM, Mohammed SK www.iosrjournals.org 97-101.

32- Landrigan PJ and. Forman JA :- Chemical pollutants, In Nelson Textbook of Pediatrics, $18^{\text {th }}$ ed. Copyright (C) 2007 Chapter 719 :3423-3327,eds.. Kliegman R. M,. Behrman R . E, Jenson H. B. , Stanton B. F. , Saunders, An Imprint of Elsevier

33- Sidhu KS, Nash DFand DE Regul MB DE . Need to revise the national drinking water regulation for copper Toxicol Pharmacol. 1995 ,22(1):95-100.

34-Potential for human exposure https://www.atsdr.cdc.gov/toxprofiles/tp132c6.pdf $6.1: 123$

35- Litonjua AA. Dietary factors and the development of asthma. Immunol Allergy Clin North Am 2008; 28: 603-29.

36-. Sackesen C, Ercan H, Dizdar E, et al. A comprehensive evaluation of the enzymatic and nonenzymatic antioxidant systems in childhood asthma. J Allergy Clin Immunol 2008; 122: 7885.

37-Kim JH, Ellwood PE, Asher MI. Diet and asthma: looking back, moving forward. Respiratory Research 2009; 12. 49:1-7

38- Fahmy B and. Cormier SA: Copper Oxide Nanoparticles Induce Oxidative Stress and Cytotoxicity in Airway Epithelial Cells Toxicol In Vitro. 2009 October; 23(7): 1365-1371.
39- Kennedy T, Ghio AJ, Reed W, Samet W, Zagorski J, Quay J, Et al. Copper-dependent Inflammation and Nuclear Factork B Activation by Particulate Air Pollution Am. J. Respir. Cell Mol. Biol. 19:366-378.

40-Iurina TM, Kupriianova TA, Chereǐskaia NK, Liamina OI, Stotskaia TV..Macro- and micro trace element of blood in elderly patients with bronchial asthma. Klin Med Mosk 2002; 80(11):30-4.

41- Urushidate S, Matsuzaka M, Okubo N, Iwasaki H, Hasebe $T$, Tsuya $R$, et al . Association between concentration of trace elements in serum and bronchial asthma among Japanese general population. J Trace Elem Med Biol. 2010;24(4):236-42 .

42- Patel MM, Lori Hoepner L, Garfinkel R, Chillrud S, Reyes A, Quinn JW Perera F, Miller RL.. Ambient Metals, Elemental Carbon, and Wheeze and Cough in New York City Children through Age 24 Months Am J Respir Crit Care Med. 2009 Dec 1;180(11):1107-13

43- Hirshon JM, Shardell M, Alles S, Powell JL, Squibb K,2 John Ondov J, and. Blaisdell CJ Elevated Ambient Air Zinc Increases Pediatric Asthma Morbidity Environ Health Perspect. 2008; 116(6): 826-831

44-. Dye JA,ehmann JR , McGee JK,. Winsett DW,1 Ledbetter AD1 Everitt J Ghio AJ,1 and. Costa DL :Acute Pulmonary Toxicity of Particulate Matter Filter Extracts in Rats: Coherence with Epidemiologic Studies in Utah Valley Residents Environ Health Perspect 2001,109(suppl 3):395-403

45-Cho WS, Rodger Duffin R, Howie SEM, Scotton CJ, Wallace WAH, William MacNee W, Bradley MB et al Progressive severe lung injury by zinc oxide nanoparticles; the role of $\mathrm{Zn} 2+$ dissolution inside lysosomes Particle and Fibre Toxicology 2011, 8:27

46-Potential for human exposure https://www atsdr.cdc.gov/toxprofiles/tp60-c6.pdf 6.7:181

47- El-Sayed WA, and Amer ER Serum copper, magnesium and zinc in wheezy infants Z.U.M.J. 19; 4; 2013 :969-975

48- Ermis B, Armutcu F, Gurel A, Kart L, Demircan N, Altin R, Demirel F. Trace Elements Status In Children With Bronchial Asthma Eur J Gen Med 2004; 1(1): 4-8

49- Kakarash TA and Al-Rabaty A : Zinc Status In Children With Bronchial Asthma, The Iraque Postgraduate Medical Journal ,2012 ,11, Suppl., 698-703 
50- Morgan CI, Ledford JR, Zhou P and Page K Zinc supplementation alters airway inflammation and airway hyper responsiveness to a common allergen http://www.journalinflammation.com/content/8/1/36.1-10

51- Rerksuppaphol $S$ and Rerksuppaphol $L$ : Zinc supplementation in children with asthma exacerbation, Pediatric Reports 2016; 8:6685, 63-67

52- Ghaffari J' Rafatpanah H , Zeinab Nazari Z and Abaskhanian A Serum Level of Trace Elements (Zinc, Lead, and Copper), Albumin and Immunoglobulins in Asthmatic Children Zahedan J Res Med Sci 2013 Sep; 15(9): 27-30

53- Ellul-Micallef $R$, Fenech F.F and Galdes A Serum zinc levels in corticosteroid-treated asthmatic patients Postgraduate Medical Journal (March 1976) 52, 148-150.

54-. Cheng WY, Tong H, Miller EW, Chang CJ, Remington J, Zucker RM et al: An integrated imaging approach to the study of oxidative stress generation by mitochondrial dysfunction in living cells. Environ Health Perspect 2010, 118:902-908.

55-. Lee SJ, Cho KS, Koh JY: Oxidative injury triggers autophagy in astrocytes: the role of endogenous zinc. Glia 2009, 57:1351-1361.

56-. Rudolf E, Cervinka M: Zinc pyrithione induces cellular stress signaling and apoptosis in Hep-2 cervical tumor cells: the role of mitochondria and lysosomes. Biometals 2010, 23:339-354.

57- Mohammed AA , Mohammed FY, El-okda E and Ahmed AB. Blood lead levels and childhood asthma Indian Ped. 2015, 52, 15,3036

58- Myers SN, Rowell B, Binns H J. Lead poisoning and asthma: An examination of comorbidity. Arch Pediatr Adolesc Med. 2002;156: 863-6.

59. Rabito FA, Horter L, Langlois EC, Carlson JC, White LE, Schwartz K, et al. Blood lead, and pediatric asthma. Epidemiology. 2013; 24: 474-6.

60-Blood lead levels in children aged between 1 and 6 years old in La Plata, Argentina.Identification of risk factors for lead exposure Arch Argent Pediatr 2016;114(6):543-548

61-Joseph CL, Havstad S, Ownby DR, Peterson EL, Maliarik asthma. Environ Health Perspect. 2005; 113: 900-4.

62- KollerK,BrownR,SpurgeonA,LevyL.Recent developments in low-level lead exposure and intellectual impairment in ,children. Environ Health Perspect 2004; 112(9):987-94.

63- Lanphear BP, Hornung R, Khoury J, Yolton $\mathbf{K}$, et al.Lowlevel environmental lead exposure and children intellectual function: an international pooled analysis. Environ Health $\begin{array}{lll}\text { Perspect } & \text { 2005;113 (7):894-9. }\end{array}$ 